\title{
Phantasmagoria:
}

\section{Ghostly entertainment of the Victorian Britain}

\author{
Yurie Nakane / Tsuda College / Tokyo / Japan
}

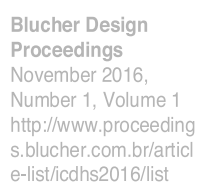

\begin{abstract}
Phantasmagoria is an early projection show using an optical instrument called a magic lantern. Brought to Britain from France in 1801, it amused spectators by summoning the spirits of absent people, including both the dead and the living. Its form gradually changed into educational amusement after it came to Britain. However, with the advent of spiritualism, its mysterious nature was re-discovered in the form of what was called 'Pepper's Ghost'. Phantasmagoria was reborn in Britain as a purely ghostly entertainment, dealing only with spirits of the dead, because of the mixture of the two notions brought from France and the United States. This paper aims to shed light on the role that phantasmagoria played in Britain during the Victorian period, how it changed, and why. Through observing the transnational history of this particular form of entertainment, we can reveal a new relationship between the representations of science and superstitions.
\end{abstract}

\section{Keywords}

Phantasmagoria, spiritualism, spectacle, ghosts, the Victorian Britain, superstitions

\section{Introduction}

Humans have been mesmerized by lights since ancient times. Handling lights was considered a deed conspiring with magic or witchcraft until the sixteenth century, owing to its sanctified appearance; thus, some performers were put in danger of persecution. At that time, most people, including aristocrats, were not scientifically educated, because science itself was in an early stage of development. However, the flourishing thought of the Enlightenment in the eighteenth century altered the situation. Entering the age of reason, people gradually came to regard illusions as worthy of scientific examination. That is, they learned to show their interests in light itself from a seemingly scientific, or seemingly logical perspective.

In that vein, many optical instruments were invented and improved, and they were introduced all over Europe in the eighteenth century. Although the complicated details have prevented recent research from verifying the origins, it is certain that Europeans at that time had a great deal of interests in optical illusions and invented one after another. Among them, the illusion that especially achieved tremendous popularity was phantasmagoria, an early projection show using an optical instrument called a 'magic lantern' (or 'phantasmagoria lantern'). Of course, its fame reached England. By the Victorian era, phantasmagoria became one of the most successful shows, and the spirit of Victorian society was greatly influenced by contemporary optical shows (Oppenheim, 1988, p.25).

Phantasmagoria parallels the social change of the age. In Victorian Britain, ghosts came to open up new possibilities for representing the era, in which a scientific education was required for a person to be an exemplary gentleman or gentlewoman. From a novel entertainment to a tool of moral or scientific education, the face of phantasmagoria had changed corresponding to social roles. However, there is no research into the Victorian spirit in phantasmagoria's transition. Even the research referred to in this paper only makes references of its achievements that elucidated the contents of the shows' performances; in other words, the Victorian mentality in phantasmagoria requires further study.

This paper aims to propose a new relationship between science and superstitions, and to examine the role of ghosts in phantasmagoria. Taking ghosts as a case study, we focus on how French phantasmagoria became a tool of scientific enlightenment in Victorian Britain, and was transformed by American spiritualism. 
Integrating three notions derived from each country into one, we show that phantasmagoria came to play a role in giving advanced knowledge to people and society. It shows us an actual power balance of these two polarised ideas at the time. The moral and rational dimensions supported by science were highly appreciated.

\section{Development of Phantasmagoria: from France to Britain}

Popularized as a novel entertainment in the eighteenth-century France, phantasmagoria spread all over the Europe. On account of its widespread nature and transformation, we first need to touch on two lanternists who performed in Paris and the traits of their phantasmagoria. Paul Philidor (also known as Paul de Philipsthal), a German performer who held phantasmagorias in Paris for the first time, and Étienne-Gaspard Robert (also known as Étienne Robertson, his stage name), a Belgian lanternist, contributed to its great success as entertainment.

Phantasmagoria in Paris was conducted by Philidor in 1792 for the first time, and was enriched as optical entertainment by Robertson. The early phantasmagoria, performed by them and their contemporaries, allowed spectators to enjoy the ghosts of the dead, living, or fictional characters, irrespective of their life, death, or reality. The shows were generally exhibited in a room or theatre of about twenty meters by seven, with a six-meter screen consisting of a curtain and mirror, as in Figure.1. Spectators, gathered in the darkened space, were frightened by the figures of a ghost and skeleton projected onto the big screen. We need to refer to the diary of François Martin Poultier-Delmotte, who joined Robertson's phantasmagoria show held on the $24^{\text {th }}$ March, 1798 . Delmotte's record vividly described the first meeting with Robertson, and the prologue, delivered by himself, claiming that he used no fraud and could display any ghost whom spectators asked him to summon in the phantasmagoria. Incidentally, when another spectator, joining in the same show, asked him to summon Louis XVI of France, he declined, saying that he had forgotten the formula to summon the King (Iwamoto, 2006, p.42-45).

All sorts of absent people, including living celebrities, were projected in French phantasmagoria to amuse spectators, though it sometimes failed due to lanternists' intended direction to forget how to summon a certain character; for there was a precedent that Philidor was once 'arrested and taken to the prison', as Marie Tussaud's biography shows, for projecting Louis XVI's ascension to heaven, though he was never intended to let him ascend (Heard, 2006, p.83).

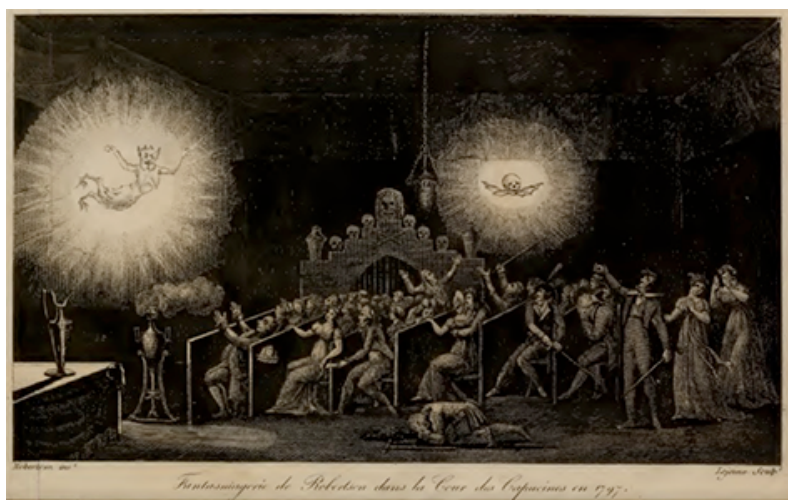

Fig. 1L 'Phantasmagoria de Robertson dans la Tour des Tapucines en 1797.' (E. G. Robertson, Mémoires Récréatifs: Scientifiques et Anecdotiques du Physicien-Aéronaute, 1831) Retrieved from

https://archive.org/details/mmoiresrcratifss01robe

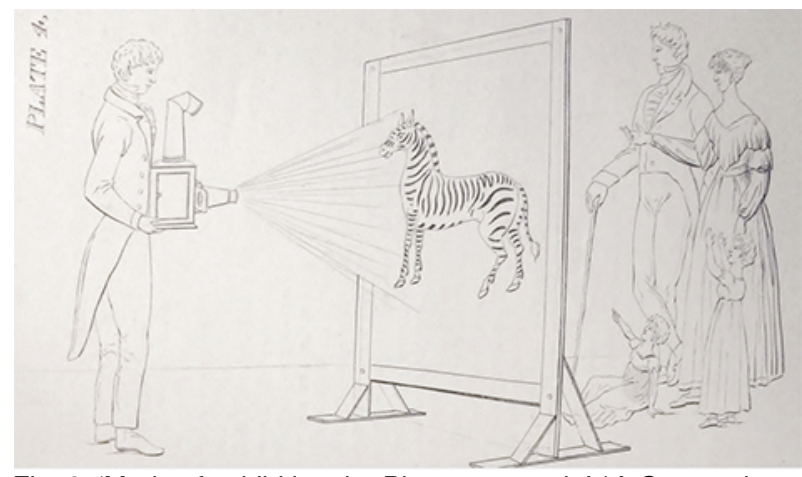

Fig. 2: 'Mode of exhibiting the Phantasmagoria' ( $A$ Companion, 1850, p.61) ( The British Library Board

In October, 1801, Paul Philidor brought phantasmagoria to Britain and started to give performances there. The first newspaper article in which phantasmagoria appears is the Morning Post on the $29^{\text {th }}$ October, 1801:

The Grand Cabinet of Optical and Mechanical Effects: in which will be produced, the phantoms or apparitions of the dead or absent, in a way more completely illusive than has ever been offered to the eye on a theatre, as the several objects freely originate in the air, and unfold themselves under various forms and sizes, such as imagination alone has hitherto painted them, occasionally amusing the figure, and most perfect resemblance of the heroes, and other distinguished characters, of past and present times ('Novel Exhibition', 1801, p.42).

As this article suggests, phantasmagoria as entertainment remained in Britain. In the same advertisement, Philidor 
was introduced by his Frenchman-like name, Paul de Phillipsthal. The uses of foreign names are commonly seen in the Victorian era to give readers a good impression. In reality, it was frequently carried out by the Victorians to apply French-sounding name to dishes, expecting to make a favourable impression (Onozuka, 2012, p.124). Likewise, it is possible that phantasmagoria was brought to Britain intentionally to be represented as French entertainment, and it was agreeable to push its Frenchness. The early phantasmagoria in Britain, its Frenchness contributing to the ghostly nature of the entertainment, broadly spread from London to every region of the country.

\section{Assimilation in the Victorian society}

Frenchness in phantasmagoria, however, gradually weakened as time passed. The slides connected with superstitious creatures, including ghosts, have been almost completely excluded from the list in a contemporary book (Fun for Winter Evenings, 1833). In the background of this disappearance is the social currency of being reluctant to discuss unintelligent things openly.

It is very unwise to terrify children.... [T] he design of this little work is to benefit the rising race, by shewing how easily we may be deceived by appearances, and that what may be thought to be supernatural objects are not so (W. Chapman, 1828, p.5).

The possible reason why the author omitted ghosts from the list of phantasmagoria slides is indicated in the quotation above. Even though phantasmagoria was intended as amusement, ghosts and other monsters terrifying children was presumably unacceptable in 'respectable' Victorian society. To make the show morally agreeable, the programmes apart from superstitious elements had to be openly advertised.

The styles and contents of phantasmagoria kept changing around the 1850s, and were adapted to Victorian society, where training people in higher morality was regarded as a duty. A contemporary work clearly refers to this change.

The Magic Lantern, which was formerly used merely to amuse children, by the exhibition of miserable caricatures and grotesque figures, has of late years amused a different character, by being adopted to the representation of subjects of Natural History, Botanical and Astronomical

Diagrams, the Costume of different countries, \&c, \&c (A Companion, 1855, p.54).

Judging from many slides categorised as 'Mammalia' and 'Portraits of the Kings and Queens of England' introduced in this work, it becomes clear that phantasmagoria had been confined to the academic sphere until the 1850s.

Compared with the eighteenth century, in which it was treated as a subject of study, we have to note that it was given an active role in people's education. What phantasmagoria began to contribute to at this point was social progress, and progress, growth, and increase in knowledge was defined as modernisation (Charlton and Andras, 2003, p.4). Phantasmagoria thus gradually symbolised modernisation from this point. The programmes terrifying children were completely deleted from the list, and themes that were instructive to children and adults were thought to be appropriate instead. What we defined as Frenchness in phantasmagoria was, at this moment, overwritten by Victorian didacticism.

In connection with that, we need to consider two significant events that happened in phantasmagoria of the day: the price reduction and the introduction of the machine itself into every home. The popularity of phantasmagoria led to many inventions and improvements to magic lanterns and their slides. While it had cost 2 shillings to join in one two-hour show in 1801 ('Novel Exhibition', 1801, p.42), Victorians around the 1850s could buy one slide from 2 shillings ( $A$ Companion, 1850, p.22) and a magic lantern from 2 pences 5 shillings (The Magic Lantern, 1865), and enjoy it whenever they pleased. Consequently, this allowed more than middle-class families to afford to enjoy their favourite shows in their own houses, and resulted in the active publication of many how-to books for the beginners. Directions were provided for these beginners to display the phantasmagoria and to give effective motion to the projected figure as shown in Figure 2 (A Companion, 1850, pp.60-65).

This domestication of phantasmagoria also owes a great deal to the activities by the Royal Polytechnic Institution (RPI). The RPI was an association of scientists established by the scientist, Sir George Cayley, in 1838 and aimed to demonstrate and publicise the latest technologies and inventions. Phantasmagoria was frequently displayed, and the mechanism of its effect scientifically explained, as part of its activities for the public. Phantasmagoria's inclusion in the science lectures at RPI, phantasmagoria effected its entrance into the academic field.

\section{Pepper's Ghost and American Influence after the 1860s}

Those who supported RPI as the home of phantasmagoria were Henry Dircks and John Henry Pepper. Henry Dircks 


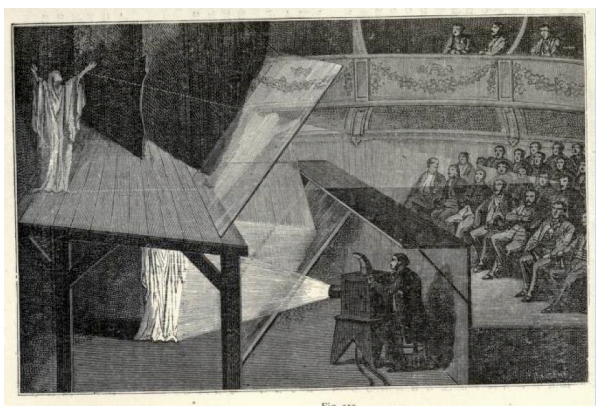

Fig. 3: 'How to exhibit Pepper's ghost.' (Natural Philosophy for General Readers and Young Persons, 1876, p.391) Retrieved from https://archive.org/details/naturalphilosoph was a civil technician who performed phantasmagoria at the RPI in the $1860 \mathrm{~s}$, based on his idea of a new style of show. His performance, called 'Dircksian Phantasmagoria', attracted many Victorians because of its novelty; however, his show 'would have required an entire specially-constructed auditorium, and even then could only be witnessed by a small number of people in an upper gallery during the hours of daylight' (Heard, 2006, p.229).

The improved version of Dirck's device was Pepper's Ghost. The system was reinvented by John Henry Pepper, a well-known chemist, though he only changed the angle of the glass plate used for Dircksian Phantasmagoria (Heard, 2006, p.229). At this point, Pepper's Ghost should also be included in the history of phantasmagoria, even though it was not referred to by the word 'phantasmagoria'. Figure 3 shows the exhibition of ghosts in Pepper's show.

Pepper's Ghost, as a new generation of phantasmagoria, meant a great change in its style. It can be said that phantasmagoria, which turned into instructive entertainment for society and contributed to the people's moral training, reacquired a very strong superstitious aspect, with the word 'ghost' as a part of its title. Still, Pepper's Ghost itself actually retained the role that phantasmagoria took after the 1820s. Pepper had 'never pretended that his ghosts were anything but illusions - as some have pointed out, a refreshing change for a time when mediums abounded who insisted that their trickery was real' (Taylor, n.d.). Phantasmagoria was involved in the very situation that should be called 'fight ghost with ghost'. At the same time, the range of topics that phantasmagoria handled was confined to spirits of the dead by the time it was reinvented as Pepper's Ghost, while its early form had included all sort of spirits. That is to say, ghosts themselves, which had been deleted from the central stage of the entertainment, were brought back to life, being entrusted with the mission scientifically to educate Victorian citizens.

We can conclude that phantasmagoria turned from a superstitious amusement into a scientifically and morally instructive one. In connection with that, the ghost was also given a new meaning as an artificially generated tool for scientific education. Because of the birth of Pepper's ghost, both phantasmagoria and ghosts are conjoined in the flow of modernisation.

\section{The Influence of Spiritualism}

As discussed above, there were various inventions and improvements brought to phantasmagoria from its establishment as a ghostly entertainment in eighteenth-century France to its transformation into the form of Pepper's Ghost in Victorian Britain. Through its history, responding to the needs of Victorian society, phantasmagoria's role transformed from mere ghostly entertainment into a way of advancing civilisation. This change should be attributed to the desire to improve corrupted Victorian British society, for it was thought at that time that much education was needed to maintain their strong empire by training acceptable citizens.

In that situation, there is an important social context to the reason why phantasmagoria regained its ghostly character through its reinvention as Pepper's Ghost. It is stated that 'the reason for Dircks' renewed activity may well have been the sudden revival of interest in ghosts, or to be more exact, ghost-raising activity that had originated in America in 1848' (Heard, 2006, p.229). The idea for having connections with dead people through spiritual interactions had been introduced to England by 1850. Although its superstitious character created many controversies over authenticity amongst its contemporaries, a new kind of belief 'became part of Victorian subculture with its mediums, specialist newspapers... private and public séances' in the 1860s (Diniejko, 2013). These situations clarify phantasmagoria's two-faced and transnational dimensions. With the advent of spiritualism, the instructiveness of phantasmagoria mingled with the American idea, and came to take on a strong superstitious aspect.

Phantasmagoria's change shows that the Victorian educational and scientific systems were supported by superstitions coming from the US. That is, two positions coexisted in phantasmagoria. From the educational point of view, it worked as a countermeasure to the entertainment's taking advantage of spreading unscientific beliefs in supernatural power. However, it must be noted that it also played a supporting role for contemporary science, judging from the example of Pepper's ghost. The change and truth of phantasmagoria reveals that superstition secretly bolstered science, while science was prone to reflect on superstition. In phantasmagoria and its ghosts were the signs of modernisation combined with Victorian pragmatism. 


\section{Conclusion}

Phantasmagoria had transformed into a symbol of the Victorian contradiction, transcending the borders between France, America, and Britain. Established in France as a ghostly entertainment dealing with spirits of absent people, it was introduced to Victorian Britain by Paul de Philipsthal, and gradually regained its instructive aspect. Although its horror was completely lost in the 1850s, when Pepper's Ghost was created by Henry Dircks and John Henry Pepper, it came to hold a more obvious ghostly essence, and was recovered as a tool to fight ghost with ghost. Conversely, the actual reason why the purely ghostly educational tool was invented was that the Victorians were keenly interested in, so to speak, the religious science called spiritualism, the American-born idea for scientifically understanding the dead. The two-sidedness of phantasmagoria shows that Victorian science actually borrowed the authority and popularity of superstitious beliefs. The entertaining character established in France was conveyed to Victorian Britain, and was integrated with the contemporary new sciences to become a purely ghostly entertainment.

Fermenting Euro-American ideas in the Victorian Britain, phantasmagoria at last took on a role in modernisation. The mixture of three conceptions, derived from the different lands and periods, also revealed the secret attitude of Victorian science towards so-called superstitions: that it took advantage of the popular spiritual theory called spiritualism. Contrary to the conventional view, these were not always polarised and confronting each other. Phantasmagoria and its ghosts came to symbolise a mutually supporting system between science and superstition, and brought modernisation to Victorian society.

\section{References}

Atkinson, E. (1876) Natural Philosophy for General Readers and Young Persons, Retrieved from https://archive.org/details/naturalphilosoph00ganorich

Chapman, W. (1828) Nocturnal Travels; or, Walks in the Night, London: Houlston and Son.

Charlton, Bruce and Andras, Peter. (2003) Modernisation Imperative, Exeter: Imprint Academic.

A Companion to the Improved Phantasmagoria Lantern, Containing a List of the Subjects (1855) London: Carpenter \& Westley.

Diniejko, Andrzej. (14 November, 2013) Victorian Spiritualism, Retrieved from http://www.victorianweb.org/victorian/religion/spirit.html.

Heard, Mervyn. (2006) Phantasmagoria: The Secret Life of the Magic Lantern, East

Sussex: The Projection Box.

Iwamoto, Kenji. (2006) Gento no Seiki: Eiga Zennya no Shikaku Bunkashi [The

Centuries of Magic Lantern: Visual Culture in Pre-Cinema History], Tokyo: Shinwa-Sha.

The Magic Lantern, Dissolving Views, and Oxy-Hydrogen Microscope (1865) London: Negretti \& Zambra.

Novel Exhibition. - Lyceum, Strand (1801, October 29) Morning Post. Retrieved from http://www.britishnewspaperarchive.co.uk/

Onozuka, Tomoji. (2012) Igirisu Ryouri ha Naze Mazui ka? [Why Are British Foods Not Very Nice?]. IN Kumie Inose (Ed.), Igirisu Bunkashi [British Cultural History], (pp. 113- 132). Kyoto: Showa-do.

Oppenheim, Janet. (1988) The Other World: Spiritualism and Psychical Research in England, 1850-1914, Cambridge: Cambridge UP.

Robertson, E. G. (1831) Mémoires Récréatifs: Scientifiques et Anecdotiques du Physicien-Aéronaute [Recreational Memories: Scientific and Anecdotical Physicist-Aeronaut], Retrieved from https://archive.org/details/mmoiresrcratifss01robe

Taylor, Troy. (n.d.) SMOKE \& MIRRORS: Making Your Own 'Ghosts' for Profit, Retrieved from http://www.prairieghosts.com/smoke.html/

West, Francis. (1833) Fun for Winter Evenings, London: J. Harris and C. Chapple.

\section{Biographical note}

Yurie NAKANE was born in Chiba, Japan in 1993. She is in the master's course in Tsuda College, Japan, and studying the Victorian death culture. Her recent interests are on the early optical entertainment called phantasmagoria and the influences the Victorian society had on it. 